\title{
DExD/H-box RNA helicase genes are differentially expressed between males and females during the critical period of male sex differentiation in channel catfish
}

\author{
Changxu Tian ${ }^{\mathrm{a}, \mathrm{b}, 1}$, Suxu Tan ${ }^{\mathrm{a}, 1}$, Lisui Bao ${ }^{\mathrm{a}}$, Qifan Zeng ${ }^{\mathrm{a}}$, Shikai Liu ${ }^{\mathrm{a}}$, Yujia Yang ${ }^{\mathrm{a}}$, \\ Xiaoxiao Zhong ${ }^{a}$, Zhanjiang Liu ${ }^{\text {a,* }}$ \\ a The Fish Molecular Genetics and Biotechnology Laboratory, Aquatic Genomics Unit, School of Fisheries, Aquaculture and Aquatic Sciences, Auburn University, Auburn, AL 36849, USA \\ b College of Fisheries, Huazhong Agricultural University, Wuhan, Hubei 430070, China
}

\section{A R T I C L E I N F O}

\section{Article history:}

Received 8 December 2016

Received in revised form 21 February 2017

Accepted 24 February 2017

Available online 1 March 2017

\section{Keywords:}

Sex differentiation

RNA helicases

Fish

Gonad development

RNA-Seq

\begin{abstract}
A B S T R A C T
DExD/H-box RNA helicases are motor proteins participating in nearly all aspects of cellular processes, especially in RNA metabolism. In this study, a total of 54 DExD/H-box RNA helicase genes including 37 DDX (DEAD-box) and 17 DHX (DEAH-box) genes were characterized in channel catfish (Ictalurus punctatus), and annotated through phylogenetic and syntenic analyses. All the catfish RNA helicases contained conserved helicase signature motifs, demonstrating that the RNA helicase gene family was highly conserved. Analysis of the relative rates of synonymous (dS) and nonsynonymous ( $\mathrm{dN}$ ) substitutions revealed that the RNA helicase genes were subjected to strong negative (purifying) selection. Meta-analysis was conducted to determine expression of the RNA helicase genes during the critical period (90-110 days post-fertilization, dpf) of male gonad differentiation. At $90 \mathrm{dpf}, 24$ RNA helicase genes were highly differentially expressed in the gonad tissues between the males and females; similarly, 24 and 18 RNA helicase genes were found highly differentially expressed in the gonad tissues between the males and females at 100 and $110 \mathrm{dpf}$, respectively $(p<0.01)$. In general, the vast majority of the RNA helicase genes (31) were expressed at higher levels in females than in males. In the male gonad, a set of 8 RNA helicases were expressed at a significantly higher level at $110 \mathrm{dpf}$ than at $90 \mathrm{dpf}$. These findings suggested that RNA helicases may play important roles in sex development and differentiation in teleosts.
\end{abstract}

(c) 2017 Elsevier Inc. All rights reserved.

\section{Introduction}

DExD/H-box RNA helicases are a group of motor proteins with important roles in regulating the reproductive-related genes by modulating mRNA structures (Schütz et al., 2010; Kotov et al., 2014). The majority of the RNA helicases are in the DEAD-box and DEAH-box families which are named after the single-letter designation of the amino acid sequence of motif II (Staley and Guthrie, 1998; Abdelhaleem et al., 2003). The core of these RNA helicases contains two tandem repeats of RecA-like globular domains connected by a flexible linker region. The N-terminal and C-terminal regions are designated as DEADdomain and helicase domain, respectively (Cordin et al., 2006; Pyle, 2008). These domains participate in RNA binding activities involving ATP hydrolysis. Nine highly conserved motifs in DEAD-box proteins (Q I, Ia, Ib, II, III, IV, V, and VI) and eight in DEAH-box proteins (I, Ia,

\footnotetext{
* Corresponding author.

E-mail address: liuzhan@auburn.edu (Z. Liu).

${ }^{1}$ C. Tian and S. Tan contributed equally to this work.
}

Ib, II, III, IV, V, and VI) are arranged sequentially and located at defined positions (Tanner et al., 2003; Tuteja and Tuteja, 2004a, 2004b). Generally, DExD/H-box RNA helicase gene families are large (Suthar et al., 2016), especially in plants. For instance, Arabidopsis thaliana, Oryza sativa, Zea mays, and Glycine max have 161, 149, 136, and 213 different RNA helicase genes, respectively (Xu et al., 2013). Fewer genes were found in animal genomes. For instance, 58 RNA helicase genes were found in Homo sapiens (Umate et al., 2011), 54 in Bos taurus (Suthar et al., 2016), 32 in Caenorhabditis elegans, and 29 in Drosophila melanogaster (Boudet et al., 2001).

DExD/H-box RNA helicases function through the modulation of RNA structures, and participate in various biological processes including premRNA splicing, ribosome biogenesis, nucleo-cytoplasmic transport, translation and RNA decay that ultimately regulate organelle gene expression for specific biological functions (Rocak and Linder, 2004). The interest in RNA helicases was further enhanced by their roles in development and reproductive processes (Owttrim, 2013). Of the RNA helicases, DDX4 (also known as Vasa) has been extensively studied; it is a germ cell marker in animals, reported to be involved in gametogenesis in Drosophila (Styhler et al., 1998; Tomancak et al., 1998) as well as 
Table 1

The channel catfish DExD/H-box RNA helicase genes. Abbreviations for protein locations are: N, nucleus; M, mitochondria; C, cytoplasm.

\begin{tabular}{|c|c|c|c|c|c|}
\hline Gene & Chromosome & $\begin{array}{l}\text { CDS } \\
\text { (bp) }\end{array}$ & $\begin{array}{l}\text { Amino } \\
\text { acids }\end{array}$ & Localization & $\begin{array}{l}\text { Accession } \\
\text { number }\end{array}$ \\
\hline DDX1 & 3 & 2223 & 740 & $\mathrm{~N}$ & KX372721 \\
\hline$D D X 2 A$ & 8 & 1221 & 406 & $\mathrm{C}, \mathrm{N}$ & JT419373 \\
\hline$D D X 2 B$ & 8 & 1236 & 411 & $\mathrm{~N}$ & JT408181 \\
\hline DDX3X & 12 & 1923 & 640 & $\mathrm{~N}$ & JT316448 \\
\hline DDX4 & 25 & 2016 & 671 & $\mathrm{~N}, \mathrm{C}$ & KM874267.1 \\
\hline DDX5 & 12 & 1836 & 611 & $\mathrm{~N}$ & JT419440 \\
\hline DDX6 & 1 & 1437 & 478 & $\mathrm{~N}, \mathrm{M}$ & JT418362 \\
\hline DDX10 & 13 & 2520 & 839 & $\mathrm{~N}$ & JT405947 \\
\hline DDX11 & 4 & 1875 & 624 & $\mathrm{~N}, \mathrm{C}$ & KX372728 \\
\hline DDX13 & 12 & 3747 & 1248 & $\mathrm{C}, \mathrm{N}$ & JT407074 \\
\hline DDX17 & 12 & 1992 & 663 & $\mathrm{~N}, \mathrm{C}$ & KX372722 \\
\hline DDX18 & 17 & 1977 & 658 & $\mathrm{~N}$ & JT417911 \\
\hline DDX19A & 15 & 1440 & 479 & $\mathrm{C}, \mathrm{N}$ & JT410544 \\
\hline DDX19B & 21 & 1440 & 479 & $\mathrm{C}, \mathrm{N}, \mathrm{M}$ & JT414565 \\
\hline DDX20 & 11 & 2094 & 697 & $\mathrm{~N}, \mathrm{M}$ & KX372723 \\
\hline DDX21 & 29 & 2298 & 765 & $\mathrm{C}, \mathrm{N}$ & KX372724 \\
\hline DDX23 & 15 & 2427 & 808 & $\mathrm{~N}$ & JT407143 \\
\hline DDX24 & 16 & 2679 & 892 & $\mathrm{~N}$ & JT418479 \\
\hline DDX27 & 7 & 2328 & 775 & $\mathrm{~N}$ & JT405367 \\
\hline DDX28 & 27 & 1698 & 565 & $\mathrm{M}, \mathrm{C}, \mathrm{N}$ & JT408085 \\
\hline DDX31 & 26 & 2142 & 713 & $\mathrm{~N}$ & JT410639 \\
\hline DDX39A & 12 & 1311 & 430 & $\mathrm{C}, \mathrm{N}$ & KX372725 \\
\hline DDX39B & 12 & 1311 & 436 & $\mathrm{C}, \mathrm{N}$ & JT417326 \\
\hline DDX41 & 3 & 1845 & 614 & $\mathrm{~N}, \mathrm{C}, \mathrm{M}$ & JT405580 \\
\hline DDX42 & 3 & 2532 & 843 & $\mathrm{C}, \mathrm{N}$ & JT416942 \\
\hline DDX43 & 25 & 1968 & 655 & $\mathrm{~N}$ & KX372729 \\
\hline DDX46 & 13 & 2613 & 870 & $\mathrm{~N}, \mathrm{C}$ & JT419149 \\
\hline DDX47 & 12 & 1410 & 469 & $\mathrm{~N}$ & KX372726 \\
\hline DDX48 & 20 & 1221 & 406 & $\mathrm{~N}$ & JT419460 \\
\hline DDX49 & 20 & 1434 & 477 & $\mathrm{~N}, \mathrm{C}$ & JT407853 \\
\hline DDX51 & 11 & 1977 & 658 & $\mathrm{~N}$ & JT405402 \\
\hline DDX52 & 13 & 1842 & 613 & $\mathrm{C}, \mathrm{N}$ & JT415605 \\
\hline DDX54 & 14 & 2583 & 860 & $\mathrm{~N}$ & JT410739 \\
\hline DDX55 & 25 & 1809 & 602 & $\mathrm{~N}, \mathrm{C}$ & JT407803 \\
\hline DDX56 & 25 & 1683 & 560 & $\mathrm{C}, \mathrm{N}$ & JT405896 \\
\hline DDX58 & 15 & 2814 & 937 & $\mathrm{C}, \mathrm{M}, \mathrm{N}$ & JT412252 \\
\hline DDX59 & 20 & 1890 & 629 & $\mathrm{~N}, \mathrm{C}$ & JT413136 \\
\hline DHX8 & 5 & 3609 & 1201 & $\mathrm{~N}$ & KX372718 \\
\hline DHX9 & 8 & 3579 & 1193 & $\mathrm{~N}, \mathrm{C}$ & KX372719 \\
\hline DHX15 & 8 & 2313 & 770 & $\mathrm{~N}$ & JT405987 \\
\hline DHX16 & 22 & 3165 & 1054 & $\mathrm{~N}$ & JT413192 \\
\hline DHX29 & 25 & 4074 & 1357 & $\mathrm{C}, \mathrm{N}, \mathrm{M}$ & JT415226 \\
\hline DHХ30 & 8 & 3501 & 1166 & $\mathrm{~N}$ & JT414412 \\
\hline DHX32A & 5 & 2232 & 743 & $\mathrm{~N}, \mathrm{C}$ & JT409383 \\
\hline DHХ32B & 6 & 2202 & 733 & $\mathrm{C}, \mathrm{N}$ & JT415634 \\
\hline DHX33 & 14 & 2043 & 680 & $\mathrm{C}, \mathrm{N}, \mathrm{M}$ & JT414119 \\
\hline DHX34 & 4 & 3351 & 1116 & $\mathrm{~N}$ & JT416192 \\
\hline DHX35 & 15 & 2079 & 692 & $\mathrm{~N}$ & JT412741 \\
\hline DHX36 & 4 & 2820 & 939 & $M, C$ & KX372730 \\
\hline DHX37 & 11 & 3453 & 1150 & $\mathrm{~N}$ & JT411419 \\
\hline DHX38 & 20 & 3813 & 1270 & $\mathrm{~N}$ & JT412543 \\
\hline DHX40 & 22 & 2214 & 737 & $\mathrm{C}, \mathrm{N}, \mathrm{M}$ & KX372727 \\
\hline DHX57 & 6 & 3945 & 1314 & $\mathrm{~N}, \mathrm{C}$ & KX372720 \\
\hline DHX58 & 3 & 2034 & 677 & $\mathrm{C}, \mathrm{M}$ & JT410933 \\
\hline
\end{tabular}

fishes like zebrafish (Bártfai and Orbán, 2003), medaka (Shinomiya et al., 2000), and tilapia (Kobayashi et al., 2000). DDX20 was essential for ovarian morphology in mice (Mouillet et al., 2008) and DDX23 was required for the sperm-oocyte switch and differentiation of various cell types in C. elegans (Konishi et al., 2008). DDX5 was highly expressed during spermatogenesis in Cherax quadricarinatus (Fang et al., 2011). A study about DHX9 deletion mutant suggested its important functions on germline transcriptional control and proliferation in C. elegans (Walstrom et al., 2005). In addition, DDX43, DDX51, and DDX55 were reported as male fertility and spermatogenesis related genes (He et al., 2012; Yousefi et al., 2015). In spite of the significant roles of the DExD/ H-box RNA helicases, they have not been systematically studied among teleost species, and their expression profiles during gonadogenesis in teleosts are unknown.
Channel catfish (Ictalurus punctatus) is a gonochoristic teleost with a XY sex-determining system (Davis et al., 1990), but the environment, especially temperature, can affect the sex ratios. It is a good model for studying the mechanisms of sex determination and differentiation because of the plasticity in sex determination (Zeng et al., 2016). The recent generation of its reference genome sequence (Liu et al., 2016), along with its gonadal transcriptome sequences generated from different developmental stages during male gonadal differentiation (Zeng et al., 2016), provided material basis for the analysis of the $\mathrm{DExD} / \mathrm{H}-$ box RNA helicase genes and their involvement in sex differentiation. In this study, we characterized a set of $54 \mathrm{DExD} / \mathrm{H}$-box RNA helicase genes from channel catfish and analyzed their expression patterns during the critical stages of male sex differentiation.

\section{Materials and methods}

\subsection{Identification and analysis of RNA helicase genes}

$\mathrm{DExD} / \mathrm{H}$-box RNA helicase genes were identified in channel catfish by screening channel catfish transcriptome database (Liu et al., 2012) and whole genome database of channel catfish (Liu et al., 2016). The DDX and DHX proteins from teleost fishes (zebrafish, fugu, medaka, tilapia, platyfish, and stickleback), amphibian (Xenopus), reptile (turtle), bird (chicken), and mammals (human and mouse) were collected and used as query sequences to search against the RNA-Seq database using TBLASTN with E-value cutoff of $\mathrm{e}^{-10}$. BLASTN program was applied to verify the retrieved cDNA sequences by aligning them with the whole genome database with E-value cutoff of $\mathrm{e}^{-10}$. The open reading frames of retrieved sequences were identified by ORF Finder (http://www.ncbi. nlm.nih.gov/gorf/gorf.html) and verified by BLASTP against NCBI nonredundant protein database. Furthermore, Simple Modular Architecture Research Tool (SMART, http://smart.embl-heidelberg.de) was used to determine the conserved domains based on sequence homology. FGENESH program (Solovyev et al., 2006) was utilized to predict coding sequences from the genome assembly. Protein localization was predicted using WoLF PSORT (http://www.genscript.com/psort/wolf_psort. html).

\subsection{Phylogenetic and syntenic analyses}

All the amino acids of $D D X$ and $D H X$ from channel catfish and other selected species (zebrafish, fugu, medaka, tilapia, platyfish, stickleback, Xenopus, turtle, chicken, human and mouse) were used for phylogenetic analysis. Multiple protein sequences alignments were conducted by MUSCLE 3.8 (Edgar, 2004). The phylogenetic trees were constructed using the maximum likelihood method in MEGA6 with bootstrap test of 1000 replicates (Tamura et al., 2013). Jones-Taylor-Thornton (JTT) and gamma distributed rate with invariant sites $(G+I)$ model were chosen based on the alignment results (Darriba et al., 2011).

In order to support the annotation $D D X$ and $D H X$ genes in channel catfish, syntenic analyses were conducted by examining the conserved co-localization of neighboring genes on reference genome sequences of channel catfish (Liu et al., 2016) and genomes of other selected species. Neighboring genes of channel catfish DDX and DHX genes were predicted by FGENESH (Solovyev et al., 2006) and BLASTP. Neighbor genes of $D D X$ and $D H X$ in other species were identified from the Ensembl and NCBI databases.

\section{3. $d N / d S$ analysis}

In order to measure the selection pressures imposed on each fish $D D X$ and $D H X$ genes, we conducted the natural selection analysis based on the relative rates of synonymous (dS) and non-synonymous $(\mathrm{dN})$ substitutions. The $\mathrm{dN} / \mathrm{dS}$ ratios at each codon site of the different RNA helicase family members were calculated using Datamonkey 
A

\begin{tabular}{|c|c|c|c|c|}
\hline DDX & Q & I & Ia & Ib \\
\hline DDXI & EWLLPTDIQ & AETGSGKT & PSKELAEQ & TPGR \\
\hline $\mathrm{DDX} 2 \mathrm{~A}$ & GFEKPSAIQ & AQSGTGKT & PTRELAQQ & TPGR \\
\hline DDX2B & GFEKPSAIQ & AQSGTGKT & PTRELAQQ & TPGR \\
\hline DDX3X & RYTRPTPVQ & AQTGSGKT & PTRELALQ & TPGR \\
\hline DDX4 & GYVKPTPVC & QAQTGSGKT & PTRELINQ & TPGR \\
\hline DDX5 & TWTEPTPIQ & AQTGSGKT & PTRELAQQ & TPGR \\
\hline DDX6 & GWEKPSPIQ & AKNGTGKS & PTRELALQ & TPGR \\
\hline DDX10 & QYRQPTEIQ & AKTGSGKT & PTRELAYQ & TPGR \\
\hline DDXII & $\cdot$ & - & - & \\
\hline DDX13 & - & AHTSAGKT & PIKALSNQ & - \\
\hline DDX17 & NFKEPTAIQ & AQTGSGKT & PTRELAQQ & TPGR \\
\hline DDX18 & GFENMTEIQ & AKTGSGKT & PTRELAMQ & TPGR \\
\hline DDX19A & GFNRPSKIQ & SQSGTGKT & PTYELALQ & TPGT \\
\hline DDX19B & GFNRPSKIQ & SQSGTGKT & PTYELALQ & TPGT \\
\hline DDX20 & GFQRPSPIQ & AKSGTGKT & PTREIAVQ & SPGR \\
\hline DDX21 & GVTHLFDIQ & ARTGTGKT & PTRELAIQ & TPGR \\
\hline DDX23 & GYKDPTPIQ & AETGSGKT & PTRELAQQ & TPGR \\
\hline DDX24 & GFSAPTPIQ & AETGSGKT & PTRELAVQ & TPGR \\
\hline DDX27 & GFKQPTPIQ & AATGTGKT & PTRELGIQ & TPGR \\
\hline DDX28 & NITHPTIVQ & AETGSGKT & PSRELAEQ & TPGA \\
\hline DDX31 & NISSMTSVQ & SQTGSGKT & PTRELAQQ & TPGR \\
\hline DDX39A & GFEHPSEVQ & AKSGMGKT & HTRELAFQ & TPGR \\
\hline DDX39B & GFEHPSEVQ & AKSGMGKT & HTRELAFQ & TPGR \\
\hline DDX41 & GIVHPTPIQ & AFTGSGKT & PSRELARQ & TPGR \\
\hline DDX42 & EYTQPTPIQ & AKTGSGKT & PTRELCQQ & TPGR \\
\hline DDX43 & GFQKPTPIQ & AQTGTGKT & PTRELALQ & TPGR \\
\hline DDX46 & NYEKPTPIQ & AKTGSGKT & PTRELALQ & TPGR \\
\hline DDX47 & GWKSPTKIO & AETGSGKT & PTRELAFQ & TPGR \\
\hline DDX48 & GFEKPSAIQ & SQSGTGKT & PTRELAGQ & TPGR \\
\hline DDX49 & GITRPTPVQ & AKTGSGKT & PTRELAYQ & TPGR \\
\hline DDX51 & GIQNFFPVQ & APTGSGKT & PTKELAQQ & TPGR \\
\hline DDX52 & GFQTPTPIQ & APTGSGKT & PTRELASQ & TPNR \\
\hline DDX54 & GYNVPTPIQ & ARTGSGKT & PTRELALQ & TPGR \\
\hline DDX55 & GFIYMTPVQ & AVTGSGKT & PTRELALQ & TPGR \\
\hline DDX56 & GWAQPTLIQ & ARTGSGKT & PTKELGQQ & TPSR \\
\hline DDX58 & - & APTGCGKT & TKVEVYEQ & TPQI \\
\hline DDX59 & GYEAPTPIQ & ADTGSGKT & PTRELAIQ & TPGR \\
\hline
\end{tabular}

\begin{tabular}{|c|c|c|c|c|c|}
\hline II & III & IV & V & VI & Protein name \\
\hline & SAT & IIF & GID & YVHRIGRVGRAE & RNA helicase DDX \\
\hline DEAD & SAT & VIF & RGID & YIHRIGRGGRFG & NA helicase elF4A-1 \\
\hline AD & SAT & VIF & RGID & YIHRIGRGGRFG & RNA helicase elF4A-2 \\
\hline & SAT & LVF & RGLD & YVHRIGRTGRVG & RNA helicase DDX3X \\
\hline $\mathrm{AD}$ & AT & MVF & RGLD & YVHRIGRTGRCG & RNA helicase DDX4 \\
\hline $\mathrm{AD}$ & $\mathrm{AT}$ & & GLD & YIHRIGRTARSQ & RNA helicase DDX5 \\
\hline EAD & SAT & IIF & RGID & YLHRIGRSGRYG & RNA helicase DDX6 6 \\
\hline EAD & SAT & IVF & RGID & YIHRVGRTARYK & RNA helicase DDX10 \\
\hline $\mathrm{AH}$ & & & & MEETGRVLSNL & se DDX11 \\
\hline $\mathrm{VH}$ & & & - & YIQMAGRAGRRG & Helicase \\
\hline $\mathrm{AD}$ & AT & & SRGLD & YVHRIGRTARST & DDX17 \\
\hline EAD & AT & MVF & GLDD & YIHRVGRTAI & DX18 \\
\hline $\mathrm{Al}$ & & MIF & & LHRIGRTGR & \\
\hline & SAT & & & & $\mathrm{X} 19 \mathrm{~B}$ \\
\hline$A D$ & & VF & GID & YMHRIGRAG & DX20 \\
\hline $\mathrm{vI}$ & AT & & & & \\
\hline A & TAT & & & & \\
\hline A & IT & VF & LD & YVH & DX24 \\
\hline & & & & & \\
\hline A & AT & & & & X28 \\
\hline $\mathrm{A}$ & iT & $\mathrm{IVF}$ & LD & YVH & XX31 \\
\hline & & & & & \\
\hline & & & & & $\mathrm{k} 39 \mathrm{~B}$ \\
\hline A & & & & & \\
\hline & & & & & \\
\hline & & & & & \\
\hline D & & & & & \\
\hline & & & & & \\
\hline & & & & & \\
\hline & & & & & \\
\hline & & & & & \\
\hline & & & & & \\
\hline DEA & & & & FLHRVGRVARAG & RNA helicase DDX54 \\
\hline & SA & LV & GID & FVHRCGRTARIG & \\
\hline & & & & & \\
\hline & & & & 'QVRGRGRAQG & \\
\hline & & & & HQIGRAGRLG & RNA helicase DDX59 \\
\hline
\end{tabular}

B

$\begin{array}{lllll}\text { DHX } & \text { I } & \text { Ia } & \text { Ib } & \text { II } \\ \text { DHX8 } & \text { GETGSGKTT } & \text { TQPRRV } & \text { TDGMLLR } & \text { DEAH } \\ \text { DHX9 } & \text { GATGCGKTT } & \text { TQPRRI } & \text { TVGVLLR } & \text { DEIH } \\ \text { DHX15 } & \text { GETGSGKTT } & \text { TQPRRV } & \text { TDGMLLR } & \text { DEAH } \\ \text { DHX16 } & \text { GETGSGKTT } & \text { TQPRRV } & \text { TDGMLLR } & \text { DEAH } \\ \text { DHX29 } & \text { GETGSGKST } & \text { TQPRRI } & \text { TTGILLR } & \text { DEVH } \\ \text { DHX30 } & \text { GETGCGKTT } & \text { TQPRRI } & \text { TVGVLLR } & \text { DEVH } \\ \text { DHX32A } & \text { GTTKTGKSS } & - & \text { TDDVLLR } & \text { DQAH } \\ \text { DHX32B } & \text { GTAKTGQST } & \text { TQIRRQ } & \text { TDHMLLS } & \text { DQAQ } \\ \text { DHX33 } & \text { GETGSGKTT } & \text { TQPRRV } & \text { TDGMLLR } & \text { DEAH } \\ \text { DHX34 } & \text { GDTGCGKST } & \text { TQPRRI } & \text { TEGLLLK } & \text { DEVH } \\ \text { DHX35 } & \text { GETGSGKST } & \text { TQPRRV } & \text { TDGMLVR } & \text { DEAH } \\ \text { DHX36 } & \text { GETGCGKTT } & \text { TQPRRI } & \text { TTGIILQ } & \text { DEIH } \\ \text { DHX37 } & \text { GETGSGKTT } & \text { TEPRRV } & \text { TDGVLLK } & \text { DEAH } \\ \text { DHX38 } & \text { GETGSGKTT } & \text { TQPRRV } & \text { TDGILLR } & \text { DEAH } \\ \text { DHX40 } & \text { GETGSGKTT } & \text { TQPRRV } & \text { TDGCMLR } & \text { DEVH } \\ \text { DHX57 } & \text { GMTGCGKTT } & \text { TQPRRI } & \text { TTGVLLR } & \text { DEVH } \\ \text { DHX58 } & \text { LPTGGGKTR } & \text { THPNGK } & \text { TAQILEN } & \text { DECH }\end{array}$

$\begin{array}{lllll}\text { III } & \text { IV } & \text { V } & \text { VI } & \text { Protein name } \\ \text { SAT } & \text { FLTG } & \text { TNIAET } & \text { QRAGRAGR } & \text { RNA helicase DHX8 } \\ \text { SAT } & \text { FLPG } & \text { TNIAET } & \text { QRKGRAGR } & \text { RNA helicase A } \\ \text { SAT } & \text { FLTG } & \text { TNIAET } & \text { QRAGRAGR } & \text { RNA helicase DHX15 } \\ \text { SAT } & \text { FLTG } & \text { TNIAET } & \text { QRAGRAGR } & \text { RNA helicase DHX16 } \\ \text { SAT } & \text { FLPG } & \text { TNIAET } & \text { QRQGRAGR } & \text { RNA helicase DHX29 } \\ \text { SAS } & \text { FLPG } & \text { TNIAET } & \text { QRRGRAGR } & \text { RNA helicase DHX30 } \\ - & \text { FLAS } & - & - & \text { RNA helicase DHX32A } \\ - & \text { FLAT } & - & - & \text { RNA helicase DHX32B } \\ \text { SAT } & \text { FMTG } & \text { TNIAET } & \text { QRAGRAGR } & \text { RNA helicase DHX33 } \\ \text { SAT } & \text { FLSG } & \text { TNIAET } & \text { QRKGRAGR } & \text { RNA helicase DHX34 } \\ \text { SAT } & \text { FLTG } & \text { TNIAET } & \text { QRAGRGGR } & \text { RNA helicase DHX35 } \\ \text { SAT } & \text { FLPG } & \text { TNIAET } & \text { QRKGRAGR } & \text { RNA helicase DHX36 } \\ \text { SAT } & \text { FLTG } & \text { TNVAET } & \text { QRAGRAGR } & \text { RNA helicase DHX37 } \\ \text { SAT } & \text { FMPG } & \text { TNIAET } & \text { QRAGRAGR } & \text { RNA helicase DHX38 } \\ \text { SAT } & \text { FLTG } & \text { TNIAAT } & \text { QRAGRAGR } & \text { RNA helicase DHX40 } \\ \text { SAT } & \text { FLPG } & \text { TNIAET } & \text { QRRGRAGR } & \text { RNA helicase DHX57 } \\ - & \text { FLTG } & \text { TSVAEE } & - & \text { RNA helicase DHX58 }\end{array}$

Fig. 1. The amino acid sequence of conserved motifs (Q I, Ia, Ib, II, III, IV, V and VI) constituting the RNA helicases of channel catfish DDX (A) and DHX (B) proteins.

(Delport et al., 2010). Only family member that has sequences originated from at least two species were selected.

\subsection{Expression analysis in channel catfish gonads}

RNA-Seq datasets of male and female gonads of channel catfish were generated from samples collected at 90,100 , and 110 days post-fertilization (dpf) (NCBI accession no. SRP067841). Expression profiles of $D D X$ and DHX genes were determined using these RNA-Seq datasets. Raw reads were trimmed and then mapped onto the channel catfish transcripts using CLC Genomics Workbench software (version 5.5.2; CLC bio, Aarhus, Denmark). Mapping parameters were set as $\geq 95 \%$ of the reads in perfect alignment and $\leq 2$ mismatches. The total mapped reads number for each transcript was determined and normalized to analyze RPKM (Reads Per Kilobase of exon model per Million mapped reads). Differentially expressed genes (DEGs) were determined based on proportions-based Kal's test with an absolute proportion fold change $\geq 2.0$ and False Discovery Rate (FDR) corrected $p$ values $<0.01$.

\subsection{Validation of differentially expressed genes by $R T-q P C R$}

We selected differentially expressed RNA helicase genes with a large fold change ( $>8$ fold) and FDR corrected $p$ values $<0.01$ for RT-qPCR validation. Primers of these genes were designed according to the assembled transcripts via Primer-BLAST (NCBI primer designing tool; http://www.ncbi.nlm.nih.gov/tools/primer-blast/) (Supplemental Table S1). The RT-qPCR calculation of relative expression levels among three groups was conducted as described by Zeng et al. (2016): four potential endogenous reference genes-18S, 28S, gusb, and tbp-were tested for their expression stability. The calculated starting concentrations of these four genes were imported into NormFinder (v0.953) to rank the stability value and select the optimal endogenous reference genes. The relative expression ratio of a target gene was calculated by Pfaffl method (Pfaffl et al., 2002). The results of investigated genes were subsequently tested for significance by a randomization test. The qPCR was repeated in triplicate runs to confirm expression patterns. For comparison of male and female gonads at 90 days post-fertilization (dpf), tbp and $18 \mathrm{~S}$ were selected as normalization genes; for comparison of male and female gonads at 100 and $110 \mathrm{dpf}, 18 \mathrm{~S}$ and gusb were selected as normalization genes; for comparison of male gonads between 90 and $110 \mathrm{dpf}$, gusb was selected as the reference gene (Zeng et al., 2016).

\section{Results}

\subsection{RNA helicase genes in channel catfish}

A total of $54 \mathrm{DExD} / \mathrm{H}$-box RNA helicase genes were identified in the channel catfish genome. Among them, 37 genes belonged to DDX family 
and 17 to DHX family. Characteristics of these genes, including their chromosomal locations, open reading frames and peptide sizes, predicted protein localization, and their GenBank accession numbers, are summarized in Table 1. These genes are located on a large number of chromosomes (21 out of a total of 29 chromosomes). Most of the RNA helicase genes are dispersed if they are on the same chromosome, but $D D X 39 A$ and DDX39B are clustered together, so are DDX4 and DDX43. The lengths of the predicted RNA helicases ranged from 406 to 1357 amino acids.

\subsection{Conserved motifs and domain structures}

The motifs and domain structures were well conserved in evolution as well as among the catfish DExD/H-box RNA helicase genes. As shown in Fig. 1A, nine motifs ( $\mathrm{Q}$ I, Ia, Ib, II, III, IV, V, and VI) were identified in the vast majority of the 37 DDX RNA helicases; similarly, as shown in Fig. 1B, the eight motifs (I, Ia, Ib, II, III, IV, V, and VI) were well conserved in the vast majority of the 17 DHX RNA helicases. However, several motifs were missing from DDX11 (Q I, Ia, Ib, III, IV, and V), DDX13 (Q Ib, III, IV, and V), DDX20 (III), and DDX58 (Q). Similarly, several motifs were missing from DHX subfamily of the RNA helicase genes such as DHX32A (motifs Ia, III, V, and VI), DHX32B (motifs III, V, and VI), and DHX58 (motifs III and VI).

Main functional domains in 54 RNA helicase genes were found in channel catfish (Fig. 2). In DDX gene family, all the DDX genes possessed DEXDc and HELICc domain. DUF4217 domain was found in four DDX genes (DDX10, DDX18, DDX31, and DDX55). DBP10CT, Znf-C2HC, KH, and DSHCT domain were only found in DDX54, DDX41,DDX43, and $D D X 13$, respectively (Fig. 2). In DHX gene family, all the $D H X$ genes contained DEXDc and HELICc domain except DHX32A and DHX32B (Fig. 2). HA2 domain was observed in all the DHX genes. Two DSRM domains were found in $\mathrm{DHX}$, and $\mathrm{Znf}-\mathrm{C} 2 \mathrm{HC}$ domain was observed in

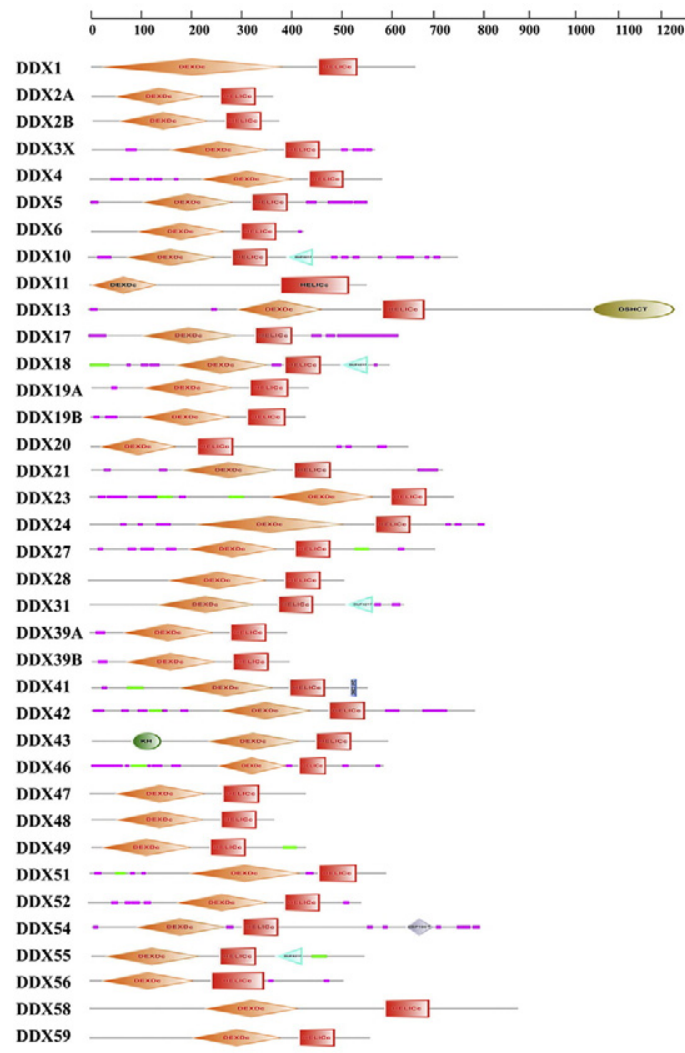

DHX34 and DHX57. PW1 and S1 domain were only found in DHX16 and $D H X 8$, respectively (Fig. 2).

\subsection{Phylogenetic and syntenic analyses of channel catfish RNA helicase genes}

Phylogenetic analysis was carried out to annotate channel catfish RNA helicases (Fig. 3A, B). In initial phylogenetic analysis, DDX and DHX genes were clustered into separate clades (data not shown). Therefore, separate phylogenetic trees were developed. In most cases, the phylogenetic analysis supported the annotation of the DDX and $D H X$ genes based on sequence similarity (Fig. 3A, B), as they were placed in the clades compatible with phylogenetic expectations with the catfish genes being most closely related to those of zebrafish except four $D D X$ genes (DDX1, DDX2A, DDX6, and DDX11) (Fig. 3A, B). For these four $D D X$ genes, syntenic analyses were further conducted in order to provide additional evidence for annotation. As shown in Fig. 4, conserved syntenic blocks were identified, and the orthologies were established among $D D X 1, D D X 2 A, D D X 6$, and $D D X 11$ from channel catfish with those from other species, indicating proper annotations.

\subsection{Gene copy number analysis of RNA helicase genes}

The comparison of the copy numbers of RNA helicase genes in channel catfish and other selected vertebrates is summarized in Table 2. The total number of the DExD/H-box RNA helicase genes were comparable among all organisms under analysis, ranging from teleost fish to amphibians, reptiles, birds, and mammals. The human DExD/H-box RNA helicase family is comprised of 58 members including 42 DDX genes and 16 DHX genes (Umate et al., 2011). Channel catfish has almost all the orthologues of DExD/H-box RNA helicase genes with exceptions: 1) It appeared that $D D X 25$ and $D D X 60$ were absent from the genomes of all analyzed fish species and Xenopus, but was present in turtle,

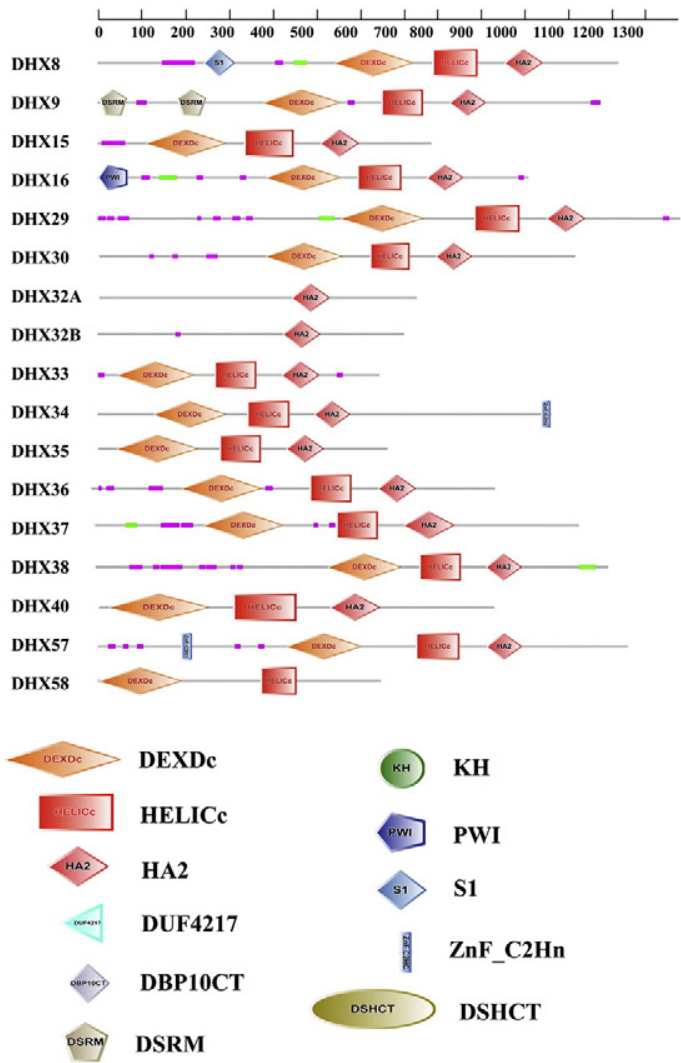

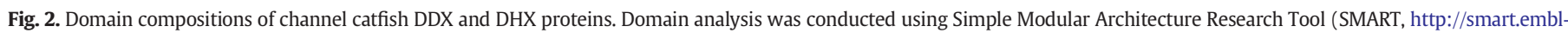
heidelberg.de). The domain structures were download and used for figure generations. 
chicken, and mammals; 2) DDX50 was absent from the genomes of teleost fish, Xenopus, and turtle, but present in the genome of chicken, mouse and human; 3 ) DDX53 was absent from all analyzed fish species as well as from the genomes of turtle, chicken and mouse, but was present in the genomes of Xenopus and human; 4) DDX47 and DDX58 were absent from all the analyzed fish species except in catfish and zebrafish; 5) DDX32 was duplicated in all fish genomes but was a single-copy gene in all other major phylogenetic groups from amphibians to mammals (Table 2).

\section{5. $d N / d S$ analysis}

The global and site-by-site dN/dS analyses for all of fish RNA helicase genes were conducted to delineate the evolution dynamics. The global ratios of $\mathrm{dN} / \mathrm{dS}$ were well below 1.0 for all genes, a theoretical boundary for positive and negative selection (Table 3 ). Strong negative and rare positive selection were detected in fish DExD/H-box RNA helicase genes (Table 3). Generally, the average $\mathrm{dN} / \mathrm{dS}$ ratio of DDXs was smaller than that of DHXs. The fish DDX20 exhibited the highest global $\mathrm{dN} / \mathrm{dS}$ ratio, followed by the DDX51. A few positive selection sites $(p<0.1)$ were found in three DHX genes (DHX36, DHX57, and DHX58), while no positive selection sites in the DDX gene family (Table 3 ). No positive selected amino acid sites were located at the nine motifs and main functional domains of RNA helicases.

\subsection{Expression analysis of RNA helicase genes in channel catfish gonads}

To determine the expression profiles of DExD/H-box RNA helicase genes during critical period of male sex differentiation, expression of the RNA helicase genes was compared between males and females in the gonad at 90,100, and $110 \mathrm{dpf}$. The most significant difference in expression levels of RNA helicase genes between male and female gonads was observed at $90 \mathrm{dpf}(p<0.01)$, followed by 100 and $110 \mathrm{dpf}$. A total of 24,24 , and 18 RNA helicase genes were highly differentially expressed in the gonad tissues between the males and females at $90 \mathrm{dpf}, 100 \mathrm{dpf}$, and $110 \mathrm{dpf}$, respectively ( $p<0.01$; Table 4). Of these, 23 genes (17 DDX and $6 D H X$ ) were expressed at higher levels in the female gonads than in the male gonads, while DDX5 was expressed lower in the female gonads than in the male gonads at $90 \mathrm{dpf}(p<0.01$; Table 4). At $100 \mathrm{dpf}, 22$ genes (16 DDX and $6 \mathrm{DHX}$ ) were expressed higher in the females than in the males, while DDX21 and $D H X 9$ were expressed higher in the males than in the females $(p<0.01$; Table 4$)$. At $110 \mathrm{dpf}, 17$ genes (11 DDX and 6 DHX) were expressed higher in the females than in the males, while DDX21 was expressed at a high

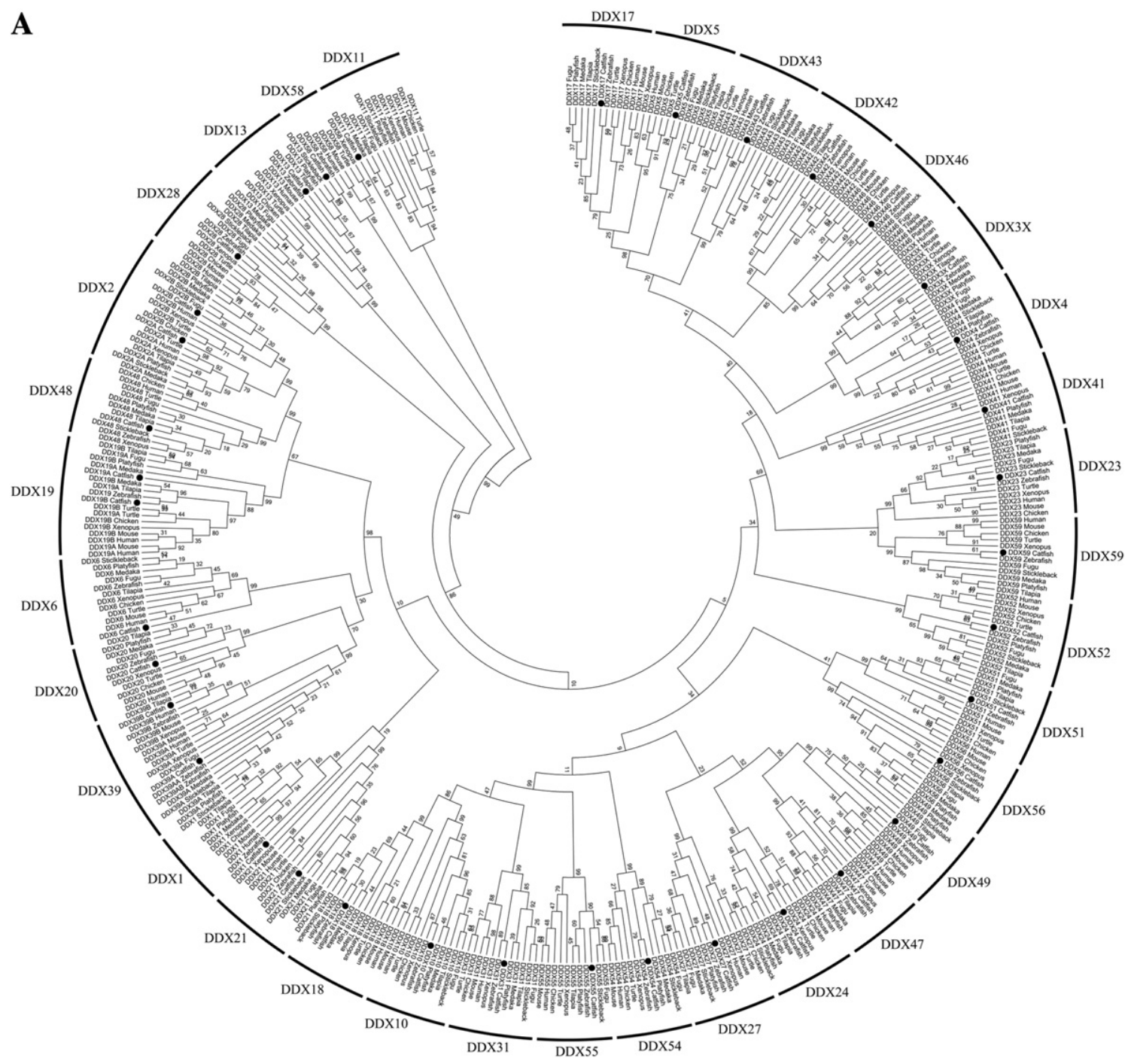

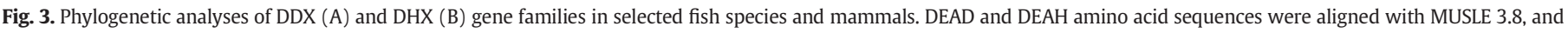

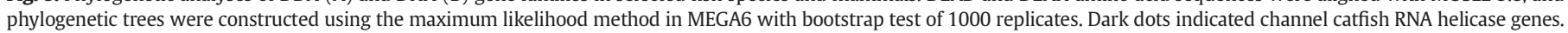
Number on each node represented bootstrap probability. The species names and accession numbers are provided in Supplemental Table S2. 
B

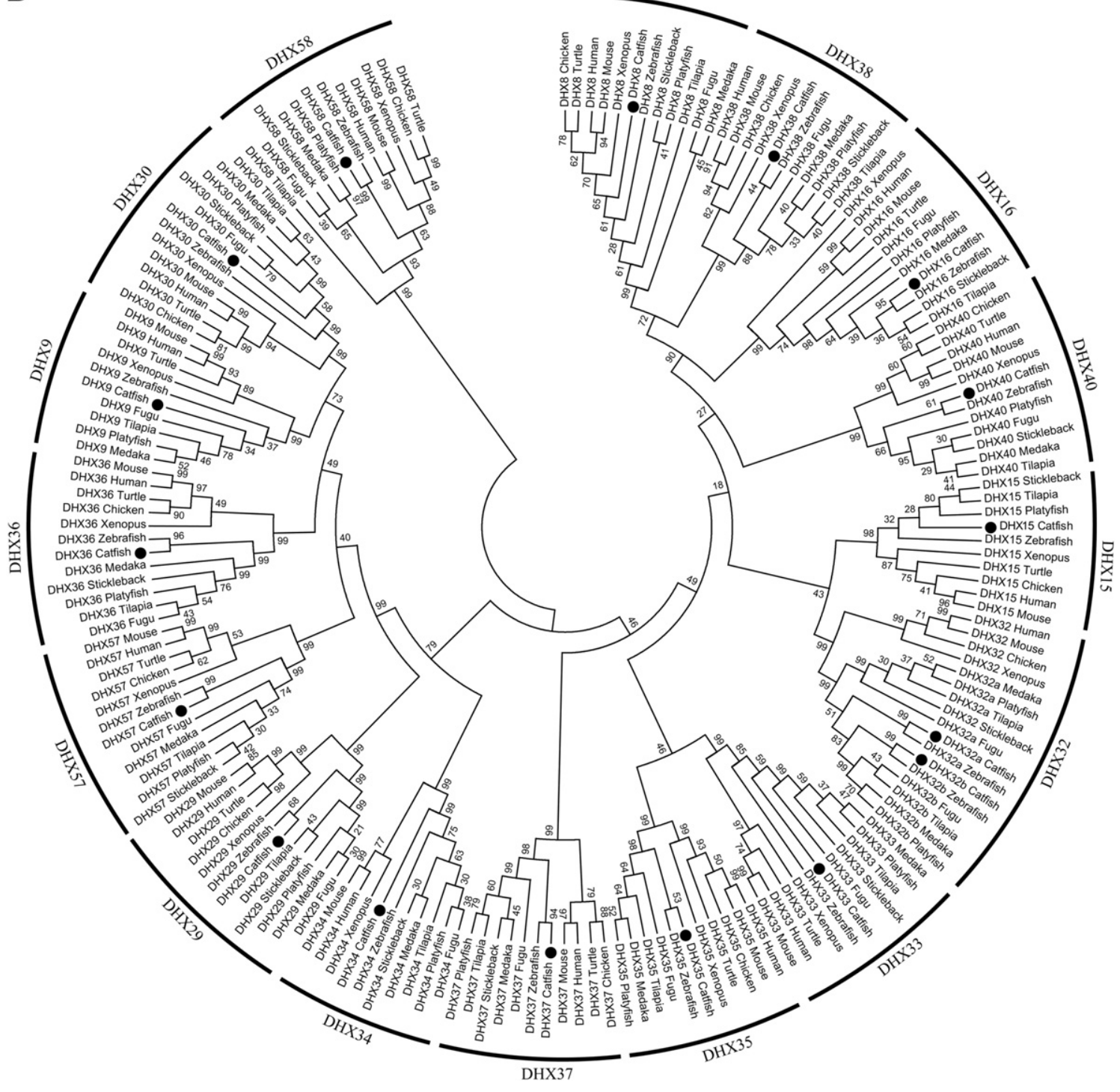

Fig. 3 (continued).

level in males ( $p<0.01$; Table 4$)$. For the most part, the vast majority of the RNA helicase genes (31) were expressed at higher levels in females than in males, with only three genes (DDX5, DDX21, and DHX9) being expressed higher in the male at one or more time points (Table 4).

Male gonads differentiation occurs between 90 and 110 days postfertilization. To determine the transcriptome profiles of DExD/H-box RNA helicase genes during catfish male gonadal differentiation, their expressions in the testes at $100 \mathrm{dpf}$ and $110 \mathrm{dpf}$ were compared with that of $90 \mathrm{dpf}$. None of DExD/H-box RNA helicase genes were expressed at significantly different levels at $100 \mathrm{dpf}$ as compared with those of the $90 \mathrm{dpf}$ (Table 5). However, nine RNA helicase genes were differentially expressed between 90 and $110 \mathrm{dpf}$. The vast majority ( 8 out of 9) of these differentially expressed genes between $90 \mathrm{dpf}$ and $110 \mathrm{dpf}$ were up-regulated, but $D D X 3 X$ was expressed lower at $110 \mathrm{dpf}$ than $90 \mathrm{dpf}$ (Table 5). Among the upregulated genes, DDX4, DDX42, and DDX32A were highly differentially expressed, with their expression 15-35 times higher at $110 \mathrm{dpf}$ than at $90 \mathrm{dpf}$.

\subsection{Validation by $R T-q P C R$}

To validate the differentially expressed genes identified by RNA-Seq, we selected differentially expressed RNA helicase genes with a large fold change ( $>8$ fold) and FDR corrected $p$ values $<0.01$ for RT-qPCR validation. For comparisons of expression between males and females at $90 \mathrm{dpf}$, eight genes were analyzed including $D D X 4, D D X 19 A, D D X 20$, DDX42, DDX43, DDX51, DHX32A, and DHX32B (Fig. 5A). Similarly, eight genes, DDX3X, DDX4, DDX19A, DDX20, DDX42, DDX43, DDX51, and DHX32A, were analyzed at $100 \mathrm{dpf}$ (Fig. 5B); five genes were analyzed for the comparison between males and females at $110 \mathrm{dpf}$ including DDX4, DDX19A, DDX43, DDX51, and DHX32A (Fig. 5C); and three genes, $D D X 4, D D X 42$, and $D H X 32 A$, were analyzed to compare the expression in the male between $90 \mathrm{dpf}$ and $110 \mathrm{dpf}$ (Fig. 5D). The results of RT-qPCR were consistent with those of RNA-Seq analyses. However, in most cases, the fold induction or repression was larger when analyzed with RT-qPCR than with RNA-Seq, but opposite patterns were observed with several genes such as DDX19A, DDX20, DDX42, DDX51, DDX32A (Fig. 5A), and DDX42 (Fig. 5B, D).

\section{Discussion}

RNA helicases are motor proteins involved in almost all the nucleic acid transactions (Abdelhaleem et al., 2003; Pyle, 2008). Although analyses of RNA helicases have been performed in various organisms including fish (Boudet et al., 2001; Abdelhaleem et al., 2003; Umate et al., 
A

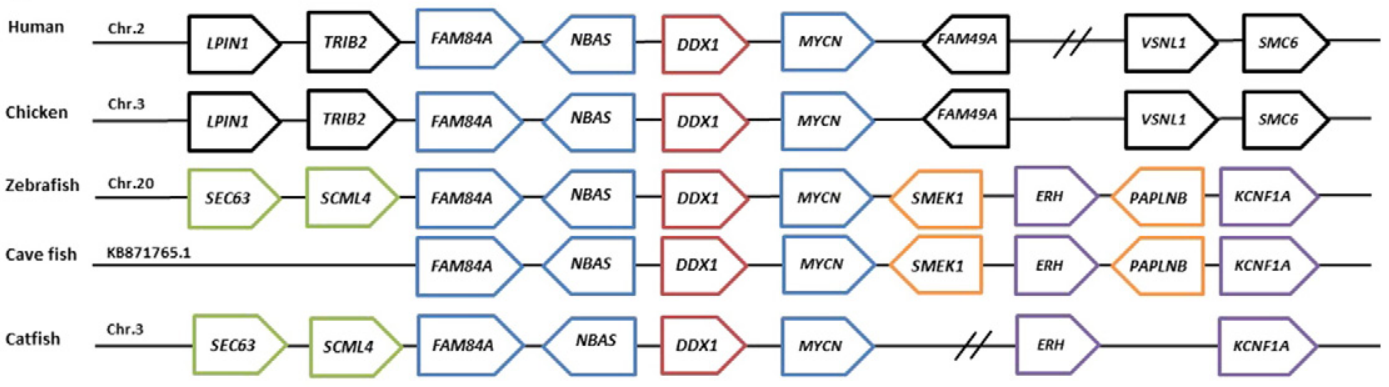

B

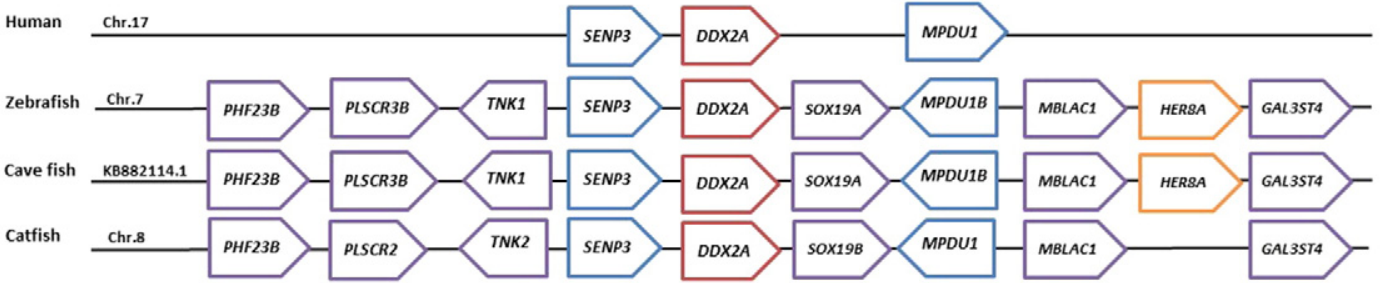

C

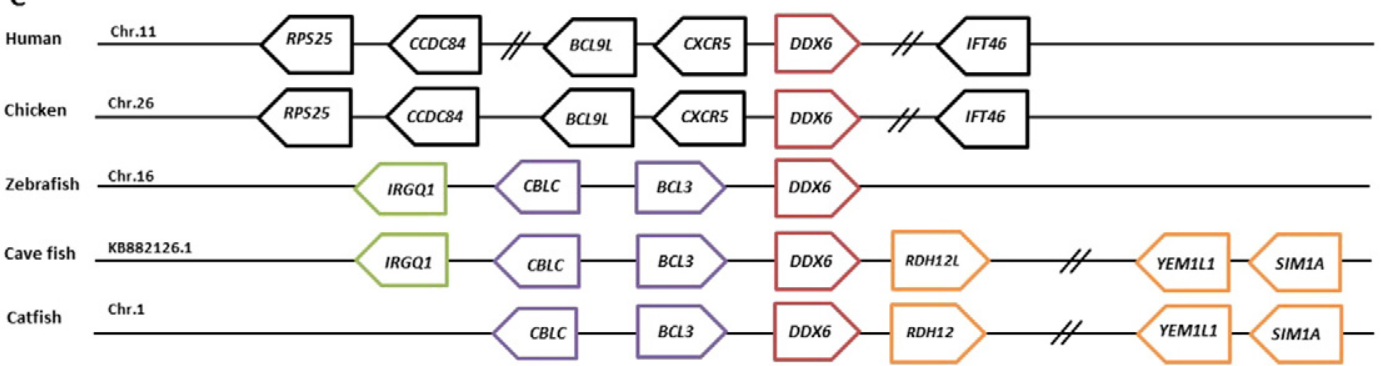

D

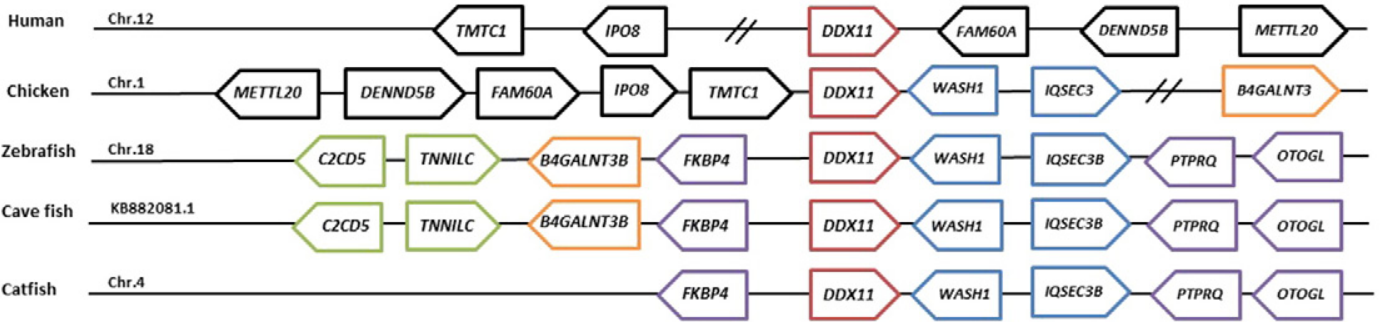

Fig. 4. Syntenic analysis of partial $D D X$ genes using genomic contexts of human, chicken, zebrafish, cave fish and channel catfish. A) $D D X 1, \mathrm{~B}) \mathrm{DDX} 2 A, \mathrm{C}) \mathrm{DDX6}$, D) $D D X 11$.

2011; Xu et al., 2013), systematic analysis of RNA helicases among teleost fish species has been lacking. In this study, $54 \mathrm{DExD} / \mathrm{H}$-box RNA helicase genes were identified in channel catfish, of which 37 genes belonged to DDX family and 17 genes to DHX family (Table 1 ). We further analyzed the structural characteristics of these genes including the conserved motifs and domains, conducted phylogenetic and syntenic analyses, delineated the evolution dynamics, determined gene copy numbers and expression profiles of the RNA helicases in the gonads of males and females.

Combining phylogenetic and syntenic analyses, all $54 \mathrm{DExD} / \mathrm{H}$ family genes were annotated. For the most part, the motifs were well conserved, spanning a broad evolutionary spectrum of species ranging from bacteria, plants, fish, to humans (Owttrim, 2013; Xu et al., 2013), suggesting RNA helicase motifs were highly conserved throughout evolution. In catfish, nine highly conserved motifs in DEAD-box proteins $(\mathrm{Q}$ I, Ia, Ib, II, III, IV, V, and VI) and eight in DEAH-box proteins (I, Ia, Ib, II, III, $\mathrm{IV}, \mathrm{V}$, and $\mathrm{VI}$ ) were also identified for the vast majority of RNA helicase genes. Although some motifs were missing from five RNA helicase genes (DDX11, DDX13, DHX32A, DHX32B, and DHX32B), several motifs were also missing from the DDX49, DHX32, DHX38, and DHX58 genes in cattle (Suthar et al., 2016) (Fig. 1), Overall, the catfish RNA helicase genes' motifs were high conserved and may contribute to the high RNA structural similarity, but their functions remained to be defined by biochemical analysis.

In this study, most of DExD/H-box RNA helicase genes showed a single-copy orthology in all the selected vertebrate species, while multiple copies were found in ten genes (DDX2, DDX3, DDX5, DDX6, DDX17, DDX19, DDX39, DHX8,DHX15, and DHX32). Almost all the genes do not have duplicated gene copies in teleosts, but just a single copy as observed with higher vertebrates. The only exception is DHX32 gene that has two copies in most of the teleost species analyzed to date (Table 2). This is quite notable as teleost fish were believed to have gone through an additional round of whole genome duplication, and therefore teleosts should harbor double copies for single copy genes in higher vertebrates. With DExD/H-box RNA helicase genes, the vast majority of the 54 catfish genes are single copy genes, suggesting the loss of gene copies after whole genome duplication was not random. Rather, it appears that most of these genes with exception of few lost the duplicated copies. Perhaps the gene copy dosage of these genes is crucially important in terms of accurate level of expression, but future research is warranted to address why almost all the RNA helicase genes are single copied in fish. In a couple of 
Table 2

Comparison of copy numbers of RNA helicase genes in selected vertebrate genomes. Species names were abbreviated: Cha: Channel Catfish; Zeb: Zebrafish; Fug: Fugu; Med: Medaka; Til: Tilapia; Sti: Stickleback; Pla: Platyfish; Xen: Xenopus; Tur: Turtle; Chi: Chicken; Mou: Mouse; Hum: Human. Yellow shading indicated duplicated genes, and gray shading indicates the absence of the specific RNA helicase genes.

\begin{tabular}{|c|c|c|c|c|c|c|c|c|c|c|c|c|}
\hline Gene & Cha & Zeb & Fug & Med & Til & Sti & Pla & Xen & Tur & Chi & Mou & Hum \\
\hline$D D X 1$ & 1 & 1 & 1 & 1 & 1 & 1 & 1 & 1 & 1 & 1 & 1 & 1 \\
\hline$D D X 2$ & 2 & 4 & 2 & 2 & 2 & 2 & 2 & 2 & 2 & 2 & 2 & 2 \\
\hline$D D X 3$ & 1 & 2 & 2 & 1 & 2 & 0 & 0 & 1 & 1 & 1 & 2 & 2 \\
\hline$D D X 4$ & 1 & 1 & 2 & 1 & 2 & 1 & 1 & 1 & 1 & 1 & 1 & 1 \\
\hline$D D X 5$ & 1 & 1 & 2 & 3 & 2 & 2 & 2 & 1 & 1 & 1 & 1 & 1 \\
\hline DDX6 & 1 & 1 & 2 & 2 & 3 & 1 & 1 & 2 & 1 & 1 & 1 & 1 \\
\hline DDX10 & 1 & 1 & 1 & 1 & 1 & 1 & 1 & 1 & 1 & 1 & 1 & 1 \\
\hline$D D X 11$ & 1 & 1 & 1 & 1 & 1 & 1 & 1 & 1 & 1 & 1 & 1 & 1 \\
\hline$D D X 13$ & 1 & 1 & 0 & 1 & 1 & 0 & 1 & 1 & 0 & 1 & 1 & 1 \\
\hline$D D X 17$ & 1 & 1 & 1 & 2 & 2 & 3 & 1 & 1 & 1 & 1 & 1 & 1 \\
\hline DDX18 & 1 & 1 & 1 & 1 & 1 & 1 & 1 & 1 & 1 & 1 & 1 & 1 \\
\hline$D D X 19$ & 2 & 2 & 2 & 2 & 2 & 1 & 2 & 1 & 1 & 1 & 2 & 2 \\
\hline DDX20 & 1 & 1 & 1 & 1 & 1 & 0 & 1 & 1 & 1 & 1 & 1 & 1 \\
\hline$D D X 21$ & 1 & 1 & 1 & 1 & 1 & 1 & 1 & 1 & 1 & 1 & 1 & 1 \\
\hline$D D X 23$ & 1 & 1 & 1 & 1 & 1 & 1 & 1 & 1 & 1 & 2 & 1 & 1 \\
\hline$D D X 24$ & 1 & 1 & 1 & 1 & 1 & 1 & 1 & 1 & 1 & 1 & 1 & 1 \\
\hline$D D X 25$ & 0 & 0 & 0 & 0 & 0 & 0 & 0 & 0 & 1 & 1 & 1 & 1 \\
\hline$D D X 27$ & 1 & 1 & 1 & 1 & 1 & 1 & 1 & 1 & 1 & 1 & 1 & 1 \\
\hline$D D X 28$ & 1 & 1 & 1 & 1 & 1 & 1 & 1 & 1 & 1 & 1 & 1 & 1 \\
\hline$D D X 31$ & 1 & 1 & 1 & 1 & 1 & 1 & 1 & 1 & 1 & 1 & 1 & 1 \\
\hline DDX39 & 2 & 3 & 3 & 2 & 3 & 2 & 2 & 2 & 1 & 0 & 2 & 2 \\
\hline$D D X 41$ & 1 & 3 & 2 & 1 & 1 & 1 & 1 & 1 & 1 & 2 & 1 & 1 \\
\hline$D D X 42$ & 1 & 1 & 1 & 1 & 1 & 1 & 1 & 1 & 1 & 1 & 1 & 1 \\
\hline$D D X 43$ & 1 & 1 & 1 & 1 & 1 & 1 & 1 & 1 & 0 & 1 & 1 & 1 \\
\hline$D D X 46$ & 1 & 1 & 1 & 1 & 1 & 1 & 1 & 1 & 1 & 1 & 1 & 1 \\
\hline$D D X 47$ & 1 & 1 & 0 & 0 & 0 & 0 & 0 & 1 & 1 & 1 & 1 & 1 \\
\hline DDX48 & 1 & 1 & 0 & 1 & 0 & 1 & 1 & 1 & 1 & 0 & 0 & 1 \\
\hline$D D X 49$ & 1 & 1 & 1 & 1 & 1 & 1 & 1 & 1 & 1 & 1 & 1 & 1 \\
\hline DDX50 & 0 & 0 & 0 & 0 & 0 & 0 & 0 & 0 & 0 & 1 & 1 & 1 \\
\hline$D D X 51$ & 1 & 1 & 1 & 1 & 1 & 1 & 1 & 1 & 1 & 0 & 1 & 1 \\
\hline DDX52 & 1 & 1 & 1 & 1 & 1 & 1 & 1 & 1 & 1 & 1 & 1 & 1 \\
\hline$D D X 53$ & 0 & 0 & 0 & 0 & 0 & 0 & 0 & 1 & 0 & 0 & 0 & 1 \\
\hline DDX54 & 1 & 1 & 1 & 1 & 1 & 1 & 1 & 1 & 1 & 1 & 1 & 1 \\
\hline DDX55 & 1 & 1 & 1 & 1 & 1 & 1 & 1 & 1 & 1 & 1 & 1 & 1 \\
\hline DDX56 & 1 & 1 & 1 & 1 & 1 & 1 & 1 & 1 & 0 & 0 & 1 & 1 \\
\hline$D D X 58$ & 1 & 1 & 0 & 0 & 0 & 0 & 0 & 1 & 0 & 0 & 1 & 1 \\
\hline$D D \times 59$ & 1 & 1 & 1 & 1 & 1 & 1 & 1 & 1 & 1 & 1 & 1 & 1 \\
\hline DDX60 & 0 & 0 & 0 & 0 & 0 & 0 & 0 & 0 & 1 & 1 & 1 & 1 \\
\hline DHX8 & 1 & 1 & 3 & 1 & 1 & 2 & 1 & 1 & 1 & 1 & 1 & 1 \\
\hline DHX9 & 1 & 1 & 1 & 1 & 1 & 0 & 1 & 1 & 1 & 0 & 1 & 1 \\
\hline DHX15 & 1 & 1 & 1 & 1 & 2 & 2 & 2 & 1 & 1 & 1 & 1 & 1 \\
\hline DHX16 & 1 & 1 & 1 & 1 & 1 & 1 & 1 & 1 & 1 & 1 & 1 & 1 \\
\hline DHX29 & 1 & 1 & 1 & 1 & 1 & 1 & 1 & 1 & 1 & 1 & 1 & 1 \\
\hline DHХ30 & 1 & 1 & 1 & 1 & 1 & 1 & 1 & 1 & 1 & 1 & 1 & 1 \\
\hline DHX32 & 2 & 2 & 2 & 2 & 2 & 1 & 2 & 1 & 1 & 1 & 1 & 1 \\
\hline DHX33 & 1 & 1 & 1 & 1 & 1 & 1 & 1 & 1 & 1 & 2 & 1 & 1 \\
\hline DHX34 & 1 & 1 & 1 & 1 & 1 & 1 & 1 & 1 & 1 & 1 & 1 & 1 \\
\hline DHX35 & 1 & 1 & 1 & 1 & 1 & 0 & 1 & 1 & 1 & 1 & 1 & 1 \\
\hline DHX36 & 1 & 1 & 1 & 1 & 1 & 1 & 1 & 1 & 1 & 1 & 1 & 1 \\
\hline DHX37 & 1 & 1 & 1 & 1 & 1 & 1 & 1 & 2 & 1 & 1 & 1 & 1 \\
\hline DHX38 & 1 & 1 & 1 & 1 & 1 & 1 & 1 & 1 & 1 & 1 & 1 & 1 \\
\hline DHX40 & 1 & 1 & 1 & 1 & 1 & 1 & 1 & 1 & 1 & 1 & 1 & 1 \\
\hline DHX57 & 1 & 1 & 1 & 1 & 1 & 1 & 1 & 1 & 1 & 1 & 1 & 1 \\
\hline DHX58 & 1 & 1 & 1 & 1 & 1 & 1 & 1 & 1 & 1 & 1 & 1 & 1 \\
\hline Total & 54 & 60 & 58 & 56 & 59 & 50 & 53 & 55 & 49 & 51 & 56 & 58 \\
\hline
\end{tabular}

cases, two copies of the RNA helicase genes existed in the genomes of mammals, and these may be from lineage-specific tandem gene duplications.

Natural selection is the major force that shapes the genetic variation within populations, and selection pressure can be measured by the relative ratios of synonymous (dS) and non-synonymous ( $\mathrm{dN}$ ) substitutions. In this study, the global ratios of $\mathrm{dN} / \mathrm{dS}$ were examined and they were found to be well below 1.0 for all RNA helicases (Table 3), a theoretical boundary for positive and negative selection (Kimura, 1977). It suggested that negative selection $(\mathrm{dN} / \mathrm{dS}<1)$ were working extensively to remove nonsynonymous substitutions from the RNA helicase genes, indicating the demand for high levels of evolutionary conservation. However, few positive selection sites $(p<0.1)$ were found in three DHX genes ( $D H X 36, D H X 57$, and DHX58) by site-by-site $\mathrm{dN} / \mathrm{dS}$ analyses (Table 3), with no positive amino acid sites located at any motifs or main functional domains. Overall, the $\mathrm{dN} / \mathrm{dS}$ ratios analysis suggested that the RNA helicase genes were highly conserved throughout the evolution.

We analyzed the expression profiles of RNA helicase genes in channel catfish gonads at 90,100, and $110 \mathrm{dpf}$, corresponding with the period of male gonad differentiation (Patiño et al., 1996). The fact that many 
Table 3

A summary description of selection pressure for each of fish DExD/H-box RNA helicase genes $(\mathrm{dN} / \mathrm{dS})$.

\begin{tabular}{|c|c|c|c|}
\hline Gene & Global dN/dS & No. of positive sites & No. of negative sites \\
\hline$D D X 1$ & 0.0716 & 0 & 245 \\
\hline$D D X 2 A$ & 0.0772 & 0 & 86 \\
\hline$D D X 2 B$ & 0.0258 & 0 & 106 \\
\hline$D D X 3 X$ & 0.1155 & 0 & 185 \\
\hline$D D X 4$ & 0.1902 & 0 & 147 \\
\hline DDX5 & 0.1143 & 0 & 196 \\
\hline DDX6 & 0.0788 & 0 & 128 \\
\hline DDX10 & 0.1869 & 0 & 183 \\
\hline DDX11 & 0.1560 & 0 & 176 \\
\hline$D D X 13$ & 0.1233 & 0 & 338 \\
\hline DDX17 & 0.1236 & 0 & 199 \\
\hline DDX18 & 0.1403 & 0 & 194 \\
\hline DDX19A & 0.1510 & 0 & 135 \\
\hline$D D X 19 B$ & 0.1364 & 0 & 36 \\
\hline DDX20 & 0.2694 & 0 & 126 \\
\hline$D D X 21$ & 0.1834 & 0 & 195 \\
\hline DDX23 & 0.0600 & 0 & 247 \\
\hline$D D X 24$ & 0.2458 & 0 & 218 \\
\hline DDX27 & 0.1406 & 0 & 242 \\
\hline DDX28 & 0.2060 & 0 & 158 \\
\hline DDX31 & 0.2274 & 0 & 152 \\
\hline DDX39A & 0.0297 & 0 & 141 \\
\hline DDX39B & 0.0398 & 0 & 4 \\
\hline DDX41 & 0.0448 & 0 & 153 \\
\hline DDX42 & 0.1071 & 0 & 281 \\
\hline DDX43 & 0.2281 & 0 & 152 \\
\hline DDX46 & 0.0818 & 0 & 299 \\
\hline$D D X 47$ & 0.1314 & 0 & 2 \\
\hline DDX48 & 0.0212 & 0 & 134 \\
\hline DDX49 & 0.1111 & 0 & 141 \\
\hline DDX51 & 0.2675 & 0 & 140 \\
\hline DDX52 & 0.2006 & 0 & 150 \\
\hline DDX54 & 0.1577 & 0 & 177 \\
\hline DDX55 & 0.1185 & 0 & 182 \\
\hline DDX56 & 0.1330 & 0 & 144 \\
\hline DDX59 & 0.1835 & 0 & 112 \\
\hline DHX8 & 0.0757 & 0 & 394 \\
\hline DHX9 & 0.1122 & 0 & 64 \\
\hline DHX15 & 0.0687 & 0 & 102 \\
\hline DHX16 & 0.0804 & 0 & 251 \\
\hline DHX29 & 0.1557 & 0 & 365 \\
\hline DHХ30 & 0.2147 & 0 & 277 \\
\hline DHX32A & 0.2260 & 0 & 135 \\
\hline DHX32B & 0.2073 & 0 & 125 \\
\hline DHX33 & 0.0832 & 0 & 196 \\
\hline DHX34 & 0.1444 & 0 & 308 \\
\hline DHX35 & 0.0571 & 0 & 104 \\
\hline DHX36 & 0.1428 & 1 & 284 \\
\hline DHX37 & 0.1512 & 0 & 331 \\
\hline DHX38 & 0.1512 & 0 & 331 \\
\hline DHX40 & 0.1283 & 0 & 184 \\
\hline DHX57 & 0.1783 & 2 & 361 \\
\hline DHX58 & 0.2477 & 1 & 143 \\
\hline
\end{tabular}

of these RNA helicase genes had different expression patterns between males and females and that many of them expressed at higher levels during the critical period of male gonad tissue differentiation (90$110 \mathrm{dpf}$ ) indicated that RNA helicases were highly relevant in catfish gonadal differentiation and development. Previous studies have shown that DExD/H-box RNA helicase genes played important roles in gametogenesis and formation of gonads during sex differentiation (Kotov et al., 2014). Especially for DDX4 gene, a number of studies showed that this particular gene displayed differential expression and sex-related expression differences during oogenesis and spermatogenesis in many fishes, including zebrafish (Krøvel and Olsen, 2004), medaka (Shinomiya et al., 2000), gibel carp (Xu et al., 2005), tilapia (Kobayashi et al., 2000, 2002), catfish (Raghuveer and Senthilkumaran, 2010) and European sea bass (Blázquez et al., 2011). In addition, several other RNA helicase genes, including DDX5, DDX20, DDX23, DDX43, DDX50, $D D X 51$, and $D H X 9$, are demonstrated to exert crucial functions in
Table 4

Differentially expressed DExD/H-box RNA helicase genes in the gonads between male and female at 90,100 , and 110 days post-fertilization (dpf). Only the significantly differentially expressed genes are listed ( $\mid$ fold change value in male / value in female $\mid \geq 2$ with the FDR corrected $p$ values $<0.01$ ). Minus indicated genes that were expressed at lower levels in male than in female.

\begin{tabular}{|c|c|c|c|}
\hline \multirow[t]{2}{*}{ Gene } & \multicolumn{3}{|c|}{ Fold change } \\
\hline & $90 \mathrm{dpf}$ & $100 \mathrm{dpf}$ & $110 \mathrm{dpf}$ \\
\hline DDX1 & -3.3 & - & - \\
\hline DDX3X & - & -8.7 & - \\
\hline DDX4 & -60.9 & -106.5 & -3.3 \\
\hline DDX5 & 4.6 & -2.8 & \\
\hline DDX10 & - & -4.9 & -5.0 \\
\hline DDX13 & - & - & -4.5 \\
\hline DDX18 & - & - & -3.2 \\
\hline DDX19A & -16.4 & -10.0 & -7.0 \\
\hline$D D X 19 B$ & -2.2 & -3.3 & - \\
\hline DDX20 & -9.9 & -7.0 & - \\
\hline DDX21 & - & 2.7 & 2.4 \\
\hline DDX23 & -4.4 & -4.4 & -2.9 \\
\hline DDX24 & -2.4 & - & - \\
\hline DDX27 & -4.0 & -5.9 & -7.0 \\
\hline DDX39A & - & -2.2 & - \\
\hline DDX41 & -5.5 & -4.9 & -3.3 \\
\hline DDX42 & -94.6 & -70.2 & - \\
\hline DDX43 & -10.2 & -11.8 & -3.5 \\
\hline DDX47 & - & - & -3.6 \\
\hline DDX49 & -5.1 & - & - \\
\hline DDX51 & -14.8 & -14.5 & -3.4 \\
\hline DDX52 & -6.2 & -7.2 & - \\
\hline DDX55 & -3.0 & & - \\
\hline DDX56 & -2.5 & - & - \\
\hline DDX59 & -5.6 & -3.8 & \\
\hline DHX9 & - & 3.6 & - \\
\hline DHX16 & -3.4 & -3.3 & -4.3 \\
\hline DHX29 & -3.6 & -4.2 & -5.3 \\
\hline DHX30 & -7.7 & -3.4 & -6.7 \\
\hline DHX32A & -102.5 & -77.4 & -3.2 \\
\hline DHХ32B & -8.1 & - & - \\
\hline DHX36 & - & -3.5 & -3.9 \\
\hline DHX38 & -2.9 & -5.1 & -4.9 \\
\hline
\end{tabular}

gametogenesis in animals (Walstrom et al., 2005; Konishi et al., 2008; Mouillet et al., 2008; Fang et al., 2011; He et al., 2012; Yousefi et al., 2015).

In this study, a total of 31 RNA helicase genes were expressed at higher levels in females, and only 3 RNA helicase genes were expressed at higher levels in males. It was shown that the gene expression of DDX4 in female-dominant group of European sea bass were always higher than that in male-dominant group (Blázquez et al., 2011). The similar result has been found in the process of Clarias gariepinus gametogenesis: the DDX4 mRNA levels gradually increased due to the increasing number of germ cells in testis and more number of primary oocytes in ovary

Table 5

Expression of DExD/H-box RNA helicase genes in testis during channel catfish male gonadal differentiation $(90,100$, and $110 \mathrm{dpf})$. Only the significantly differentially expressed genes are listed ( $\mid$ fold change value at $100 \mathrm{dpf}$ or $110 \mathrm{dpf} /$ value at $90 \mathrm{dpf} \mid \geq 2$ with the FDR corrected $p$ values $<0.01)$. Minus indicated genes that were expressed at higher levels in male at $90 \mathrm{dpf}$ than at $110 \mathrm{dpf}$

\begin{tabular}{lll}
\hline Gene & Fold change & \\
\cline { 2 - 3 } & $100 \mathrm{dpf} v \mathrm{~d}$ & $110 \mathrm{dpf}$ vs \\
& $90 \mathrm{dpf}$ & $90 \mathrm{dpf}$ \\
\hline DDX3X & - & -2.2 \\
$D D X 4$ & - & 14.7 \\
$D D X 20$ & - & 2.8 \\
$D D X 41$ & - & 2.8 \\
$D D X 42$ & - & 35.7 \\
$D D X 51$ & - & 4.9 \\
$D D X 52$ & - & 2.3 \\
$D D X 59$ & - & 3.2 \\
$D H X 32 A$ & - & 27.8 \\
\hline
\end{tabular}


A

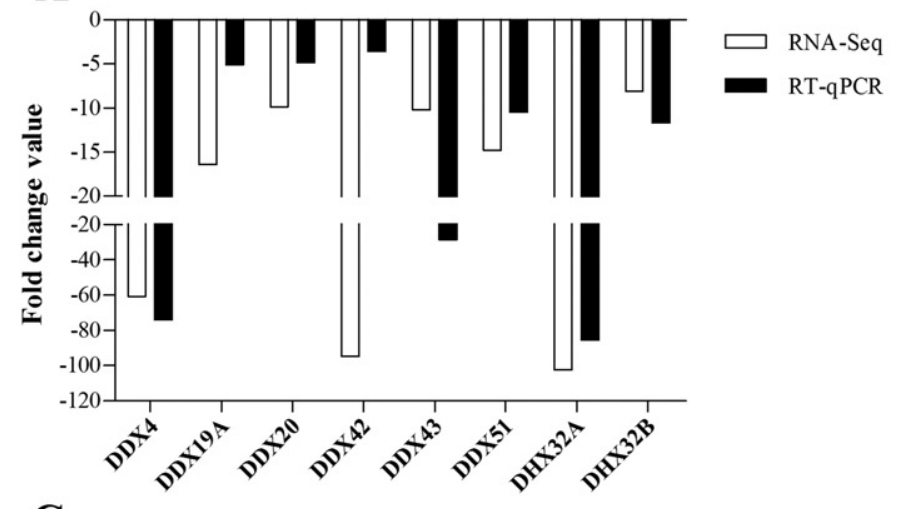

C

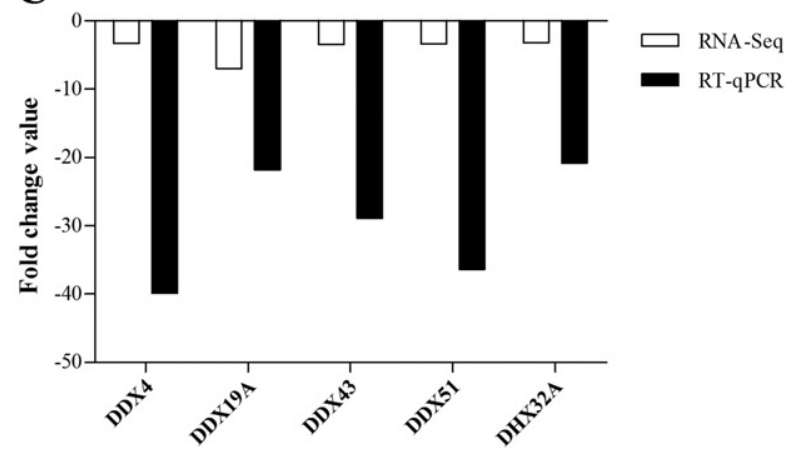

B
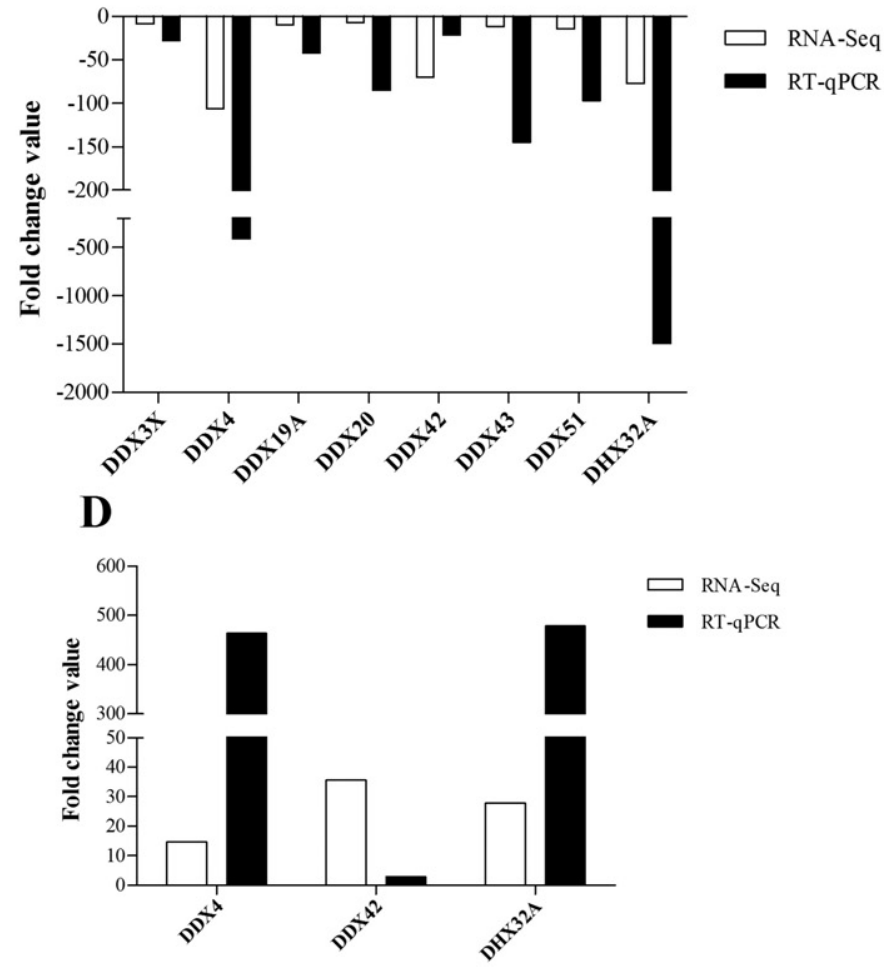

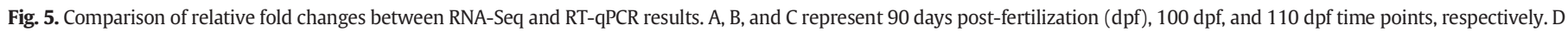
represents the changes between $90 \mathrm{dpf}$ and $110 \mathrm{dpf}$ in the male gonad.

(Raghuveer and Senthilkumaran, 2010). In channel catfish, ovarian differentiation began at $19 \mathrm{dpf}$, while testicular formation normally started between 90 and 102 dpf (Patiño et al., 1996). In that regard, sex differentiation during the studied period had already taken place in females and female gonad development was in an advanced stage. Therefore, female gonads are bigger and should contain more germ cells than male gonads. Consequently, the differential expression level of the RNA helicases in male and female could be attributed not only to sex, but also to differential gonad growth at this developmental stage (Papadaki et al., 2005; Raghuveer and Senthilkumaran, 2010; Blázquez et al., 2011). Taken together, these observations suggested that the RNA helicase genes may be regulated in a sex-specific as well as developmental stage-specific manner for germ cell development and sex differentiation in channel catfish.

In addition, nine genes were highly expressed in the male gonads at $110 \mathrm{dpf}$ as compared to their levels of expression at $90 \mathrm{dpf}$ in this study. In channel catfish male gonads, transcriptomic profiles at $90 \mathrm{dpf}$ and $100 \mathrm{dpf}$ exhibited high similarities, while drastic changes were observed during 90-110 dpf, with a group of highly up-regulated genes involved in germ cells development (Zeng et al., 2016). The gene expression patterns may suggest that the major events for male sex differentiation occur between 100 and $110 \mathrm{dpf}$, and the RNA helicase genes may be involved in catfish testicular development. Functional analysis is required to determine how the RNA helicases exert their functions for male sex differentiation.

\section{Conclusions}

A total of $54 \mathrm{DExD} / \mathrm{H}$-box RNA helicase genes of channel catfish were identified and characterized in this study. Phylogenetic and syntenic analyses were conducted to clearly establish their orthologies, supporting their annotations. Strong negative and rare positive selection were detected in fish RNA helicase genes by dN/dS analysis. The meta-analysis of DExD/H-box RNA helicase genes in gonad differentiation were conducted, with a fraction of genes of the most highly changed expression validated using RT-qPCR. The expression patterns, especially the significant differences between males and females, and between $90 \mathrm{dpf}$ and $110 \mathrm{dpf}$, suggested significant involvement of the DExD/H-box RNA helicases in sex development and differentiation.

\section{Acknowledgements}

This project was supported by grants from the Animal Health Program and Animal Genetics, Genomics and Breeding Program of the Agriculture and Food Research Initiative (AFRI) of the USDA National Institute of Food and Agriculture (NIFA), Grant no. 2017-67015-26295. Changxu Tian was supported by a scholarship from the China Scholarship Council (CSC).

\section{Appendix A. Supplementary data}

Supplementary data to this article can be found online at http://dx. doi.org/10.1016/j.cbd.2017.02.008.

\section{References}

Abdelhaleem, M., Maltais, L., Wain, H., 2003. The human DDX and DHX gene families of putative RNA helicases. Genomics 81, 618-622.

Bártfai, R., Orbán, L., 2003. The vasa locus in zebrafish: multiple RGG boxes from duplications. DNA Cell Boil. 22, 47-54.

Blázquez, M., González, A., Mylonas, C.C., Piferrer, F., 2011. Cloning and sequence analysis of a vasa homolog in the European sea bass (Dicentrarchus labrax): tissue distribution and mRNA expression levels during early development and sex differentiation. Gen. Comp. Endocrinol. 170, 322-333.

Boudet, N., Aubourg, S., Toffano-Nioche, C., Kreis, M., Lecharny, A., 2001. Evolution of intron/exon structure of DEAD helicase family genes in Arabidopsis, Caenorhabditis and Drosophila. Genome Res. 11, 2101-2114.

Cordin, O., Banroques, J., Tanner, N.K., Linder, P., 2006. The DEAD-box protein family of RNA helicases. Gene 367, 17-37.

Darriba, D., Taboada, G.L., Doallo, R., Posada, D., 2011. ProtTest 3: fast selection of best fit models of protein evolution. Bioinformatics 27, 1164-1165. 
Davis, K.B., Simco, B.A., Goudie, C.A., Parker, N.C., Cauldwell, W., Snellgrove, R., 1990 Hormonal sex manipulation and evidence for female homogamety in channel catfish. Gen. Comp. Endocrinol. 78, 218-223.

Delport, W., Poon, A.F., Frost, S.D., Kosakovsky Pond, S.L., 2010. Datamonkey 2010: a suite of phylogenetic analysis tools for evolutionary biology. Bioinformatics 26 , 2455-2457.

Edgar, R.C., 2004. MUSCLE: multiple sequence alignment with high accuracy and high throughput. Nucleic Acids Res. 32, 1792-1797.

Fang, D.A., Wang, Q., Wang, J., He, L., Liu, L.H., Wang, Y., 2011. A novel DDX5 gene in the freshwater crayfish Cherax quadricarinatus is highly expressed during ontogenesis and spermatogenesis. Genet. Mol. Res. 10, 3963-3975.

He, L., Wang, Q., Jin, X., Wang, Y., Chen, L., Liu, L., Wang, Y., 2012. Transcriptome profiling of testis during sexual maturation stages in Eriocheir sinensis using Illumina sequencing. PLoS One 7, e33735.

Kimura, M., 1977. Preponderance of synonymous changes as evidence for the neutra theory of molecular evolution. Nature 267, 275-276.

Kobayashi, T., Kajiura-Kobayashi, H., Nagahama, Y., 2000. Differential expression of vasa homologue gene in the germ cells during oogenesis and spermatogenesis in a teleost fish, tilapia, Oreochromis niloticus. Mech. Dev. 99, 139-142.

Kobayashi, T., Kajiura-Kobayashi, H., Nagahama, Y., 2002. Two isoforms of vasa homologs in a teleost fish: their differential expression during germ cell differentiation. Mech. Dev. 111, 167-171.

Konishi, T., Uodome, N., Sugimoto, A., 2008. The Caenorhabditis elegans DDX-23, a homo$\log$ of yeast splicing factor PRP28, is required for the sperm-oocyte switch and differentiation of various cell types. Dev. Dyn. 237, 2367-2377.

Kotov, A.A., Akulenko, N.V., Kibanov, M.V., Olenina, L.V., 2014. DEAD-box RNA helicases in animal gametogenesis. Mol. Biol. 48, 16-28.

Krøvel, A., Olsen, L., 2004. Sexual dimorphic expression pattern of a splice variant of zebrafish vasa during gonadal development. Dev. Biol. 271, 190-197.

Liu, S.K., Zhang, Y., Zhou, Z., Waldbieser, G., Sun, F., Lu, J., Zhang, J., Jiang, Y., Zhang, H., Wang, X., Rajendran, K., Khoo, L., Kucuktas, H., Peatman, E., Liu, Z., 2012. Efficient assembly and annotation of the transcriptome of catfish by RNA-Seq analysis of a doubled haploid homozygote. BMC Genomics 13, 595

Liu, Z.J., Liu, S.K., Yao, J., Bao, L.S., Zhang, J.R., Li, Y., Jiang, C., Sun, L.Y., Wang, R.J., Zhang, Y., Zhou, T., Zeng, Q.F., Fu, Q., Gao, S., Li, N., Koren, S., Jiang, Y.L., Zimin, A., Xu, P., Phillippy, A.M., Geng, X., Song, L., Sun, F.Y., Li, C., Wang, X.Z., Chen, A.L., Jin, Y.L., Yuan, Z.H., Yang Y.J., Tan, S.X., Peatman, E., Lu, J.G., Qin, Z.K., Dunham, R., Li, Z.X., Sonstegard, T., Feng, J.B., Danzmann, R.G., Schroeder, S., Scheffler, B., Duke, M.V., Ballard, L., Kucuktas, H. Kaltenboeck, L., Liu, H.X., Armbruster, J., Xie, Y.J., Kirby, M.L., Tian, Y., Flanagan, Elizabeth M., Mu, W.J., Waldbieser, G.C., 2016. The channel catfish genome sequence provides insights into the evolution of scale formation in teleosts. Nat. Commun. 7: 11757. http://dx.doi.org/10.1038/ncomms11757.

Mouillet, J.F., Yan, X., Ou, Q., Jin, L., Muglia, L.J., Crawford, P.A., Sadovsky, Y., 2008. DEADbox protein-103 (DP103, Ddx20) is essential for early embryonic development and modulates ovarian morphology and function. Endocrinology 149, 2168-2175.

Owttrim, G.W., 2013. RNA helicases: diverse roles in prokaryotic response to abiotic stress. RNA Biol. 10, 96-110.

Papadaki, M., Piferrer, F., Zanuy, S., Maingot, E., Divanach, P., Mylonas, C., 2005. Growth, sex differentiation and gonad and plasma levels of sex steroids in male and femaledominant populations of Dicentrarchus labrax obtained through repeated size grading. J. Fish Biol. 66, 938-956.

Patiño, R., Davis, K.B., Schoore, J.E., Uguz, C., Strüssmann, C.A., Parker, N.C., Goudie, C.A. 1996. Sex differentiation of channel catfish gonads: normal development and effects of temperature. J. Exp. Zool. 276, 209-218.
Pfaffl, M.W., Horgan, G.W., Dempfle, L., 2002. Relative expression software tool (REST) for group-wise comparison and statistical analysis of relative expression results in realtime PCR. Nucleic Acids Res. 30, e36.

Pyle, A.M., 2008. Translocation and unwinding mechanisms of RNA and DNA helicases. Annu. Rev. Biophys. 37, 317-336.

Raghuveer, K., Senthilkumaran, B., 2010. Cloning and differential expression pattern of vasa in the developing and recrudescing gonads of catfish, Clarias gariepinus. Comp. Biochem. Physiol. A Mol. Integr. Physiol. 157, 79-85.

Rocak, S., Linder, P., 2004. DEAD-box proteins: the driving forces behind RNA metabolism. Nat. Rev. Mol. Cell Biol. 5 (232-24).

Schütz, P., Karlberg, T., van den Berg, S., Collins, R., Lehtiö, L., Högbom, M., Moche, M., 2010. Comparative structural analysis of human DEAD-box RNA helicases. PLoS One 5, e12791.

Shinomiya, A., Tanaka, M., Kobayashi, T., Nagahama, Y., Hamaguchi, S., 2000. The vasa-like gene, olvas, identifies the migration path of primordial germ cells during embryonic body formation stage in the medaka, Oryzias latipes. Develop. Growth Differ. 42, 317-326.

Solovyev, V., Kosarev, P., Seledsov, I., Vorobyev, D., 2006. Automatic annotation of eukaryotic genes, pseudogenes and promoters. Genome Biol. 7 (1), 1.

Staley, J.P., Guthrie, C., 1998. Mechanical devices of the spliceosome: motors, clocks, springs, and things. Cell 92, 315-326.

Styhler, S., Nakamura, A., Swan, A., Suter, B., Lasko, P., 1998. Vasa is required for GURKEN accumulation in the oocyte, and is involved in oocyte differentiation and germline cyst development. Development 125, 1569-1578.

Suthar, M.K., Purva, M., Maherchandani, S., Kashyap, S.K., 2016. Identification and in silico analysis of cattle DExH/D box RNA helicases. Springerplus 5, 1-13.

Tamura, K., Stecher, G., Peterson, D., Filipski, A., Kumar, S., 2013. MEGA6: molecular evolutionary genetics analysis version 6.0. Mol. Biol. Evol. 30, 2725-2729.

Tanner, N.K., Cordin, O., Banroques, J., Doere, M., Linder, P., 2003. The Q motif: a newly identified motif in DEAD box helicases may regulate ATP binding and hydrolysis. Mol. Cell 11, 127-138

Tomancak, P., Guichet, A., Zavorszky, P., Ephrussi, A., 1998. Oocyte polarity depends on regulation of gurken by vasa. Development $125,1723-1732$

Tuteja, N., Tuteja, R., 2004a. Prokaryotic and eukaryotic DNA helicases. Essential molecular motor proteins for cellular machinery. Eur. J. Biochem. 271, 1835-1848.

Tuteja, N., Tuteja, R., 2004b. Unraveling DNA helicases. Motif, structure, mechanism and function. Eur. J. Biochem. 271, 1849-1863.

Umate, P., Tuteja, N., Tuteja, R., 2011. Genome-wide comprehensive analysis of human helicases. Commun. Integr. Biol. 4, 118-137.

Walstrom, K.M., Schmidt, D., Bean, C.J., Kelly, W.G., 2005. RNA helicase A is important for germline transcriptional control, proliferation, and meiosis in C. elegans. Mech. Dev. 122, 707-720.

Xu, H., Gui, J., Hong, Y., 2005. Differential expression of vasa RNA and protein during spermatogenesis and oogenesis in the gibel carp (Carassius auratus Gibelio), a bisexually and gynogenetically reproducing vertebrate. Dev. Dyn. 233, 872-882.

Xu, R., Zhang, S., Huang, J., Zheng, C., 2013. Genome-wide comparative in silico analysis of the RNA helicase gene family in Zea mays and Glycine max: a comparison with Arabidopsis and Oryza sativa. PLoS One 8, e78982.

Yousefi, P., Huen, K., Davé, V., Barcellos, L., Eskenazi, B., Holland, N., 2015. Sex differences in DNA methylation assessed by $450 \mathrm{~K}$ bead chip in newborns. BMC Genomics 16, 1 .

Zeng, Q.F., Liu, S.K., Yao, J., Zhang, Y., Yuan, Z.H., Jiang, C., Chen, A.L., Fu, Q., Su, B.F., Dunham, R., Liu, Z.J., 2016. Transcriptome Display during Testicular Differentiation of Channel Catfish (Ictalurus punctatus) as Revealed by RNA-Seq Analysis. http:// dx.doi.org/10.1095/biolreprod.116.138818. 